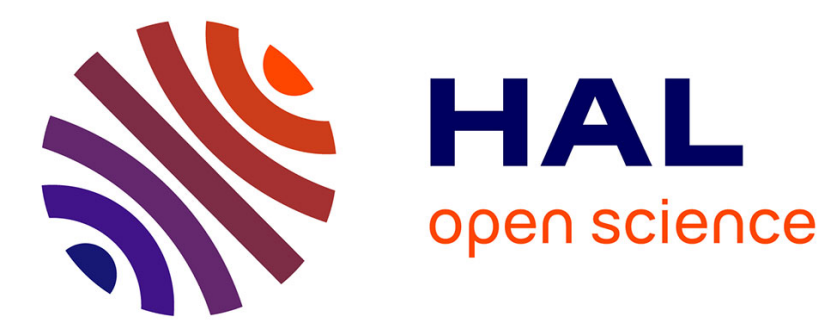

\title{
Effects of peptides derived from dietary proteins on mucus secretion in rat jejunum
}

Jean Claustre, Férial Toumi, Aurélien Trompette, Gérard Jourdan, Henri

Guignard, Jean-Alain Chayvialle, Pascale Plaisancié

\section{To cite this version:}

Jean Claustre, Férial Toumi, Aurélien Trompette, Gérard Jourdan, Henri Guignard, et al.. Effects of peptides derived from dietary proteins on mucus secretion in rat jejunum. AJP - Gastrointestinal and Liver Physiology, 2002, 283 (3), pp.G521-G528. hal-02678147

\section{HAL Id: hal-02678147 https://hal.inrae.fr/hal-02678147}

Submitted on 31 May 2020

HAL is a multi-disciplinary open access archive for the deposit and dissemination of scientific research documents, whether they are published or not. The documents may come from teaching and research institutions in France or abroad, or from public or private research centers.
L'archive ouverte pluridisciplinaire HAL, est destinée au dépôt et à la diffusion de documents scientifiques de niveau recherche, publiés ou non, émanant des établissements d'enseignement et de recherche français ou étrangers, des laboratoires publics ou privés. 
Jean Claustre, Férial Toumi, Aurélien Trompette, Gérard Jourdan, Henri

Guignard, Jean Alain Chayvialle and Pascale Plaisancié

Am J Physiol Gastrointest Liver Physiol 283:521-528, 2002. doi:10.1152/ajpgi.00535.2001

You might find this additional information useful...

This article cites 39 articles, 15 of which you can access free at:

http://ajpgi.physiology.org/cgi/content/full/283/3/G521\#BIBL

This article has been cited by 6 other HighWire hosted articles, the first 5 are:

Intestinal Inflammation Increases Gastrointestinal Threonine Uptake and Mucin Synthesis in Enterally Fed Minipigs

D. Remond, C. Buffiere, J.-P. Godin, P. P. Mirand, C. Obled, I. Papet, D. Dardevet, G.

Williamson, D. Breuille and M. Faure

J. Nutr., April 1, 2009; 139 (4): 720-726.

[Abstract] [Full Text] [PDF]

Feeding Dietary Peptides to Growing Rats Enhances Gut Endogenous Protein Flows Compared with Feeding Protein-Free or Free Amino Acid-Based Diets

A. Deglaire, P. J. Moughan, S. M. Rutherfurd, C. Bos and D. Tome

J. Nutr., November 1, 2007; 137 (11): 2431-2436.

[Abstract] [Full Text] [PDF]

Leptin modulates the expression of secreted and membrane-associated mucins in colonic epithelial cells by targeting PKC, PI3K, and MAPK pathways

M. E. Homsi, R. Ducroc, J. Claustre, G. Jourdan, A. Gertler, M. Estienne, A. Bado, J.-Y. Scoazec and P. Plaisancie

Am J Physiol Gastrointest Liver Physiol, July 1, 2007; 293 (1): G365-G373.

[Abstract] [Full Text] [PDF]

beta-Casomorphin-7 regulates the secretion and expression of gastrointestinal mucins through a $\{$ micro\}-opioid pathway

S. Zoghbi, A. Trompette, J. Claustre, M. E. Homsi, J. Garzon, G. Jourdan, J.-Y. Scoazec and P. Plaisancie

Am J Physiol Gastrointest Liver Physiol, June 1, 2006; 290 (6): G1105-G1113.

[Abstract] [Full Text] [PDF]

Dietary peptides increase endogenous amino acid losses from the gut in adults

P. J Moughan, C. A Butts, A. M Rowan and A. Deglaire

Am. J. Clinical Nutrition, June 1, 2005; 81 (6): 1359-1365.

[Abstract] [Full Text] [PDF]

Medline items on this article's topics can be found at http://highwire.stanford.edu/lists/artbytopic.dtl

on the following topics:

Biochemistry .. Mucus Glycoproteins

Biochemistry .. Casein

Biochemistry .. Nutrient and Storage Proteins

Physiology .. Jejunum

Sociology .. Drug Abuse

Physiology .. Rats

Updated information and services including high-resolution figures, can be found at:

http://ajpgi.physiology.org/cgi/content/full/283/3/G521

Additional material and information about AJP - Gastrointestinal and Liver Physiology can be found at: http://www.the-aps.org/publications/ajpgi

This information is current as of September 6, 2010 .

AJP - Gastrointestinal and Liver Physiology publishes original articles pertaining to all aspects of research involving normal or abnormal function of the gastrointestinal tract, hepatobiliary system, and pancreas. It is published 12 times a year (monthly) by the American Physiological Society, 9650 Rockville Pike, Bethesda MD 20814-3991. Copyright @ 2002 by the American Physiological Society. ISSN: 0193-1857, ESSN: 1522-1547. Visit our website at http://www.the-aps.org/. 


\title{
Effects of peptides derived from dietary proteins on mucus secretion in rat jejunum
}

\author{
JEAN CLAUSTRE, ${ }^{1}$ FÉRIAL TOUMI, ${ }^{1}$ AURÉLIEN TROMPETTE, ${ }^{1}$ GÉRARD JOURDAN,${ }^{1}$ \\ HENRI GUIGNARD,${ }^{1}$ JEAN ALAIN CHAYVIALLE, ${ }^{1}$ AND PASCALE PLAISANCIÉ ${ }^{1,2}$ \\ ${ }^{1}$ Institut National de la Santé et de la Recherche Médicale U45, Hôpital Edouard Herriot, \\ 69437 Lyon Cedex 3; and ${ }^{2}$ Laboratoire d'Ecologie et de Physiologie du Système Digestif, Institut National \\ de la Recherche Agronomique, Centre de Recherche de Jouy-en-Josas, 78352 Jouy-en-Josas Cedex, France
}

Received 7 January 2002; accepted in final form 20 March 2002

\begin{abstract}
Claustre, Jean, Férial Toumi, Aurélien Trompette, Gérard Jourdan, Henri Guignard, Jean Alain Chayvialle, and Pascale Plaisancié. Effects of peptides derived from dietary proteins on mucus secretion in rat jejunum. Am J Physiol Gastrointest Liver Physiol 283: G521-G528, 2002; 10.1152/ajpgi.00535.2001.-The hypothesis that dietary proteins or their hydrolysates may regulate intestinal mucin discharge was investigated in the isolated vascularly perfused rat jejunum using an enzyme-linked immunosorbent assay for rat intestinal mucins. On luminal administration, casein hydrolysate $[0.05-5 \%(\mathrm{wt} / \mathrm{vol})]$ stimulated mucin secretion in rat jejunum (maximal response at $417 \%$ of controls). Lactalbumin hydrolysate (5\%) also evoked mucin discharge. In contrast, casein, and a mixture of amino acids was without effect. Chicken egg albumin and its hydrolysate or meat hydrolysate also did not modify mucin release. Interestingly, casein hydrolysate-induced mucin secretion was abolished by intra-arterial TTX or naloxone (an opioid antagonist). $\beta$-Casomorphin-7, an opioid peptide released from $\beta$-casein on milk ingestion, induced a strong mucin secretion (response at $563 \%$ of controls) that was inhibited by naloxone. Intra-arterial $\beta$-casomorphin-7 also markedly increased mucin secretion ( $410 \%$ of controls). In conclusion, two enzymatic milk protein hydrolysates (casein and lactalbumin hydrolysates) and $\beta$-casomorphin-7, specifically, induced mucin release in rat jejunum. The casein hydrolysate-induced mucin secretion is triggered by a neural pathway and mediated by opioid receptor activation.
\end{abstract}

goblet cells; casein; lactalbumin; $\beta$-casomorphin; isolated perfused intestine

A MAJOR FACTOR OF THE FUNCTIONAL barrier of intestine is luminal mucus gel. The mucus coat separates mucosal cells from the exterior milieu and provides protection from noxious substances, allows lubrication of the cell surface, and regulates ion fluxes (10). Mucus, therefore, plays an important role for the intestinal surface integrity in health, and dysfunction of mucus secretion and/or mucin expression could be involved in several pathologies such as inflammatory intestinal diseases and cancer $(16,41)$. For these reasons, there is a need for better knowledge of the regulation of mucus secretion. In particular, very little is known about the mod-

Address for reprint requests and other correspondence: P. Plaisancié, INSERM U45, Pavillon Hbis, 2ème étage, Hôpital Ed. Herriot, 69437 Lyon Cedex 03, France (E-mail: plaisancie@lyon151.inserm.fr). ulation of intestinal mucus secretion by dietary factors, although the interactions of dietary components with the secretory activity of goblet cells could represent new interesting possibilities for the manipulation of this important protective function.

Mucins, the predominant components of the mucus gel, are high-molecular weight glycoproteins with oligosaccharides attached by $O$-glycosidic bonds to serine or threonine residues on a peptide backbone. In rat small and large intestine, secreted mucins are primarily accounted for by rMuc2 (40) and are mainly synthesised by epithelial goblet cells (or mucus cells) (36). Previous experiments performed either in vivo or ex vivo have demonstrated that dietary fibers and shortchain fatty acids may alter the dynamics of mucus through increased secretion, tissue content, or even altered mucus cell number $(2,18,27,28,35)$. In contrast, no information on the impact of proteins is available. Dietary proteins and their degradation products are yet involved in the physiological regulation of digestion. In particular, proteins or digested proteins stimulate cholecystokinin release and interact with intestinal endocrine L cells to modulate glucagonlike peptide-1 secretion $(4-6,17)$. Partial hydrolysates of proteins are also potent stimulants of gastric acid and pancreatic secretion and participate in the regulation of gastrointestinal motility through stimulation of the adrenergic pathway $(11,15,20)$. Furthermore, Roberts et al. (26) demonstrated that some dietary peptides may improve wound healing in rats.

The present study was undertaken to determine the effects of dietary proteins or their enzymatic hydrolysates on intestinal goblet cell secretion. For this purpose, we used the preparation of isolated vascularly perfused rat jejunum. This model provides a unique opportunity to study the secretion of mucus in response to well-defined luminal stimuli in a manner that eliminates extraneous influences potentially encountered in vivo. The polarized mucus cells may thus be submitted to specific stimulation with dietary proteins or their products of hydrolysis at a site where nutrient

The costs of publication of this article were defrayed in part by the payment of page charges. The article must therefore be hereby marked "advertisement" in accordance with 18 U.S.C. Section 1734 solely to indicate this fact. 
derivatives interact physiologically with the intestinal mucosa. The subsequent jejunal mucin discharge was evaluated by ELISA.

\section{MATERIALS AND METHODS}

\section{Materials}

BSA was purchased from Biomedia (Boussens, France). Nutrilamine 25, a mixture of amino acids, was obtained from Braun Medical (Boulogne, France). Pancreatic digest of lactalbumin (LH, peptone $n^{\circ} 60$, ref 20025-037) was from GIBCO-BRL (life Technologies, Cergy Pontoise, France). $\beta$-Casomorphin ( $\beta$-CM)-7 was obtained from Bachem (Bubendorf, Switzerland). TTX was supplied by Calbiochem (Darmstadt, Germany). Naloxone was purchased from ICN pharmaceuticals (Costa Mesa, CA). Microtiter plates (NUNCImmunoplate) were obtained from Polylabo (Paul Block \& Cie, Strasbourg, France). Cesium Chloride and DIG glycan detection kit were supplied by Boehringer (Mannheim, Germany). Electrophoresis products were obtained from Bio-Rad (Hercules, CA). Other reagents, including casein from bovine milk (sodium salt, ref C-8654), casein enzymatic hydrolysate from bovine milk (type II, ref C-4523), chicken egg albumin (crude, grade II, ref A-5253), chicken egg albumin hydrolysate (ref A-3154), and type I enzymatic hydrolysate from meat (peptone, ref P-7750) were purchased from Sigma (Saint Louis, MO).

\section{Animal Model and Experimental Protocol}

Surgical preparation. The operative procedure to prepare an isolated vascularly perfused rat jejunum was previously described (7). Briefly, male Wistar rats $(250-350 \mathrm{~g})$ purchased from Le Centre d'Elevage Dépré (Saint Doulchard, France) were anesthetized with pentobarbital sodium (50 $\mathrm{mg} / \mathrm{kg}$ ip). The right and middle colic veins and arteries were tied and cut off near the serosa of the colon. Both ends of the jejunal loop (12 cm in length, $2 \mathrm{~cm}$ beyond the ligament of Treitz) were then equipped with Silastic tubing. The jejunal lumen was flushed out with prewarmed isotonic saline and then with air. After the air was gently emptied, both ends of the intestinal loop were ligated. A metal cannula and a Silastic one were then quickly inserted in the superior mesenteric artery and portal vein, respectively. The arterial perfusion started immediately at a rate of $2.5 \mathrm{ml} / \mathrm{min}$ with a Krebs-Henseleit buffer [(in mM) $2 \mathrm{CaCl}_{2}, 6 \mathrm{KCl}, 3.18$ $\mathrm{NaH}_{2} \mathrm{PO}_{4}, 104 \mathrm{NaCl}, 1 \mathrm{MgSO}_{4}$, and $41.6 \mathrm{NaHCO}_{3}, \mathrm{pH}$ 7.4] containing $25 \%$ washed bovine erythrocytes, $3 \%$ BSA, $5 \mathrm{mM}$ glucose, and $1 \%$ Nutrilamine $25(\mathrm{vol} / \mathrm{vol})$ and continuously gassed with $\mathrm{O}_{2}-\mathrm{CO}_{2}(95: 5 \%)$. The preparation was then removed and transferred to a bath containing isotonic saline at $37^{\circ} \mathrm{C}$. The pressure of perfusion, continuously recorded with a mercury manometer, ranged from 40 to $55 \mathrm{mmHg}$. In preliminary experiments, the viability of the preparation was found to be $1-2 \mathrm{~h}$.

Experimental protocol. The experiments consisted of a 5 -min equilibration period followed by a 30 -min stimulation period. Immediately after the equilibration period, the loops were filled by injection with $0.8 \mathrm{ml}$ of prewarmed isotonic saline (control preparations or arterial stimulations) or with $0.8 \mathrm{ml}$ luminal factors at $37^{\circ} \mathrm{C}$. When required, the $\mathrm{pH}$ of luminal compounds to be tested was adjusted to $7-7.5$ with diluted hydrochloric acid, and the osmolarity was adjusted to $300 \mathrm{mosmol} / \mathrm{kgH}_{2} \mathrm{O}$ with sodium chloride. A control experiment was performed for each stimulated loop.

In some experiments, $10^{-6} \mathrm{M}$ TTX or $10^{-5} \mathrm{M}$ naloxone was administered intra-arterially after 2 min of equilibration and maintained over the 30-min period of stimulation. All vascularly perfused drugs were dissolved in Krebs-Henseleit buffer supplemented with $3 \%$ BSA and were delivered at a rate of $0.25 \mathrm{ml} / \mathrm{min}$ through a catheter close to the vascular inflow.

At the end of the experimental period, loops were cut at both ends and fluid content was collected. To remove the mucus adherent to the mucosal surface, loops were carefully emptied by manual massage, flushed with $4 \mathrm{ml}$ isotonic saline $\left(37^{\circ} \mathrm{C}\right)$ and with air, then drained. Luminal content (fluid content + adherent mucus gel) was weighed, sonicated, and frozen at $-20^{\circ} \mathrm{C}$ for subsequent determination of mucinlike immunoreactivity and luminal DNA content. The adherent mucus gel was taken into account because it represents a substantial part of the secreted immunoreactive material. The empty jejunal loops were weighed, and the length was measured (in $\mathrm{cm}$ ). Jejunal loops were then homogenized (Ultra-Turrax, Janke and Kundel, Staufen, Germany) for 1 min in PBS, and homogenates were stored at $-20^{\circ} \mathrm{C}$. Tissue homogenates were then analyzed for DNA content.

Analysis of samples. Samples of luminal contents were incubated for $24 \mathrm{~h}$ with $100 \mathrm{mM}$ 1,4-dithiothreitol (DTT) at $4^{\circ} \mathrm{C}$ for reduction and were then assayed for mucin glycoproteins by an ELISA (see Immunoassay). Samples of luminal stimulants were also assayed for checking the absence of interference in the ELISA.

Jejunal loop homogenates were thawed and briefly homogenized. Aliquots were sonicated for $20 \mathrm{~s}$ and then analyzed for DNA content using the fluorimetric method of Hinegardner (14). The amount of mucin glycoproteins secreted from each loop was expressed as micrograms of mucin per milligram of tissue DNA, and the results were expressed as percent controls. Samples of luminal content were also analyzed for DNA content. This analysis served as an indirect measure of tissue viability, and loops were discarded if luminal DNA content represented $>2 \%$ of the total DNA (tissue DNA + luminal DNA).

\section{Purification of Mucin and Development of an Immunoassay}

Preparation of rat intestinal mucin. Rat intestinal mucins (RIM) were purified using essentially the same procedure as described for rat colonic mucins $(24,40)$. Briefly, male Wistar rats were killed by a lethal dose of pentobarbital sodium. Their small intestines were rapidly excised lengthwise and rinsed in cold PBS $\left(4^{\circ} \mathrm{C}\right)$. The mucosa was then gently scraped off, and scrapings were homogenized by moderate stirring in the dark for $24 \mathrm{~h}$ at $4^{\circ} \mathrm{C}$ in $50 \mathrm{mM}$ Tris buffer $(\mathrm{pH}$ 7.5) containing $6 \mathrm{M}$ guanidinium hydrochloride, protease inhibitors (1 mM phenylmethylsulfonyl fluoride, $5 \mathrm{mM}$ EDTA, $10 \mathrm{mM}$ benzamidine hydrochloride, $0.1 \mathrm{mg} / \mathrm{ml}$ soybean trypsin inhibitor, and $10 \mu \mathrm{g} / \mathrm{ml}$ pepstatin) and $100 \mathrm{mM}$ DTT. Sulfhydride groups were stabilized by carboxymethylation with $250 \mathrm{mM}$ iodoacetamide and stirring in the dark for $24 \mathrm{~h}$. Insoluble material was removed by centrifugation (30 min, 18,500 rpm, $4^{\circ} \mathrm{C}$ ). Mucins were then purified by equilibrium centrifugation on three consecutive $\mathrm{CsCl}$ density gradients (Centrikon T-2055 ultracentrifuge, TFT 50.38 rotor, $40,000 \mathrm{rpm}, 70 \mathrm{~h}, 12^{\circ} \mathrm{C}$ ) as described for rat colonic mucins (24). The high-molecular weight nature of purified mucins was verified by SDS-PAGE and Western blot using an immunological detection system for glycoproteins (DIG Glycan detection kit) (13).

Development of antisera. Antisera against RIM were obtained in rabbits after repeated injections of the purified mucins $(250 \mu \mathrm{g})$. The presence of anti-RIM antibody was assessed by dot blot. Briefly, serial dilutions (from 6.25 to 200 $\mu \mathrm{g} / \mathrm{ml}$ ) of purified mucins were blotted on nitrocellulose. 
Blots were incubated with anti-RIM $(1: 1,000$ or $1: 5,000)$ and then with goat anti-rabbit IgG conjugated to horseradish peroxidase $(1: 1,000)$. Blots were developed using the enhanced chemiluminescence method (chemiluminescence, Pierce, Rockford, IL). The serum with the highest antibody titer (59C) was selected. On dot blot, no reaction was observed with bovine albumin, bovine thyroglobulin, bovine apolipoprotein A-II, bovine apolipoprotein B, human immunoglobulin, bovine glycoprotein $\alpha$-acid, bovine submaxillary mucin, pectin, and gum arabic. The antiserum 59C was also studied for epitope specificity. Purified mucins were digested with $0.1 \mathrm{mg} / \mathrm{ml}$ proteinase $\mathrm{K}$ in $50 \mathrm{mM}$ Tris buffer, $\mathrm{pH} 7.4$ (1 $\mathrm{h}, 37^{\circ} \mathrm{C}$ ), to assess the reactivity toward protease-sensitive epitopes. The digested mucins were blotted on nitrocellulose and processed as described previously. Proteolytic digestion of the purified mucins with proteinase $\mathrm{K}$ resulted in a very strong decrease in reactivity on dot blot (data not shown), thus suggesting that protease-sensitive domains in purified mucins were required for antibody binding.

Recognition of intestinal mucins by anti-RIM was controlled histologically. Sections $(5 \mu \mathrm{m})$ of paraffin-embedded jejunal tissue were incubated with diluted normal blocking serum and then with anti-RIM antiserum (1:500 dilution). After sections were washed in PBS, they were sequentially exposed to biotinylated goat anti-rabbit antibody, to avidin/ biotinylated peroxidase complex (Vectastain Elite ABC Reagent), and 3,3'-diaminobenzidine solution (all from Vector Laboratories, Burlingame, CA). The sections were then counterstained, cleared, and mounted. Antiserum 59C reacted with intestinal goblet cells as well as with the mucus layer, as shown in Fig. 1. In control experiments, substituting antiserum for a preincubated antigen-antiserum mix gave no reaction toward mucus cells (Fig. 1).

An immunoglobulin-rich fraction of serum 59C was purified on Protein A Sepharose CL-4B column (Pharmacia, Uppsala, Sweden) and used to prepare labeled antibody (biotinylated59C) for the ELISA using a succinimide ester of biotin (12).

Immunoassay. An ELISA for rat intestinal mucin glycoproteins was then established. Wells of a microtiter plate were coated with $100 \mu$ l of purified mucins or with sample diluted in carbonate buffer ( $\mathrm{pH}$ 9.6) and then incubated overnight at $4^{\circ} \mathrm{C}$. On the following day, the microtiter plate was washed four times with PBS containing $0.1 \%$ Tween (PBS-Tween, $\mathrm{pH}$ 7.2). The remaining binding sites in the wells were blocked by addition of $250 \mu \mathrm{l}$ of PBS-Tweenbovine albumin (0.2 g albumin in $100 \mathrm{ml}$ PBS-Tween) (PBSTween-BA) for $1 \mathrm{~h}$ at $37^{\circ} \mathrm{C}$, and the plate was washed again. At this stage, the wells were incubated with $100 \mu \mathrm{l}$ of biotinylated-59C $(7.5 \mu \mathrm{g} / \mathrm{ml})$ diluted in PBS-Tween-BA for $1 \mathrm{~h}$ at $37^{\circ} \mathrm{C}$. After the wells were washed, $100 \mu \mathrm{l}$ of avidine-peroxidase conjugate were added and allowed to bind for $1 \mathrm{~h}$ at room temperature. The plate was washed five times. One hundred microliters of $O$-phenylenediamine dihydrochloride solution were then added, the color was allowed to develop in the dark for 5-10 min, and the reaction was stopped with 25 $\mu \mathrm{l}$ of $3 \mathrm{M}$ sulfuric acid. The absorbance was read at $492 \mathrm{~nm}$ on a microELISA plate reader. A typical standard curve was obtained by using increasing concentrations (0-1,000 ng dry $\mathrm{wt} / \mathrm{ml}$ ) of purified mucins. The curve was linear in a 62.5- to $1,000-\mathrm{ng} / \mathrm{ml}$ range. Luminal contents were tested at three dilutions (1:1,000, 1:2,000, and 1:4,000), and all the assays were performed in duplicate. The coefficient of variation of the ELISA was $4.5 \%$. Serial dilutions of luminal samples taken from control or from stimulated loops gave results in ELISA that could be superimposed on the standard curve (data not shown). This immunoreactive material was distributed like purified rat intestinal mucins on a $\mathrm{CsCl}$ density gradient, with a peak at a density of $1.4 \mathrm{~g} / \mathrm{ml}$, which is characteristic of mucins $(40,42)$.

\section{Statistical Analysis}

Data are presented as means $\pm \mathrm{SE}$ and were compared using repeated-measures ANOVA followed by paired $t$-test when appropriate. $P<0.05$ was considered significant.

\section{RESULTS}

\section{Effects of Native and Enzymatically Hydrolyzed Dietary Proteins on Mucin Secretion in Rat Jejunum}

The casein hydrolysate $(\mathrm{CH})$ we used is a highly refined trypsin hydrolysate from Sigma (ref C-4523). In the isolated vascularly perfused rat jejunum, luminal
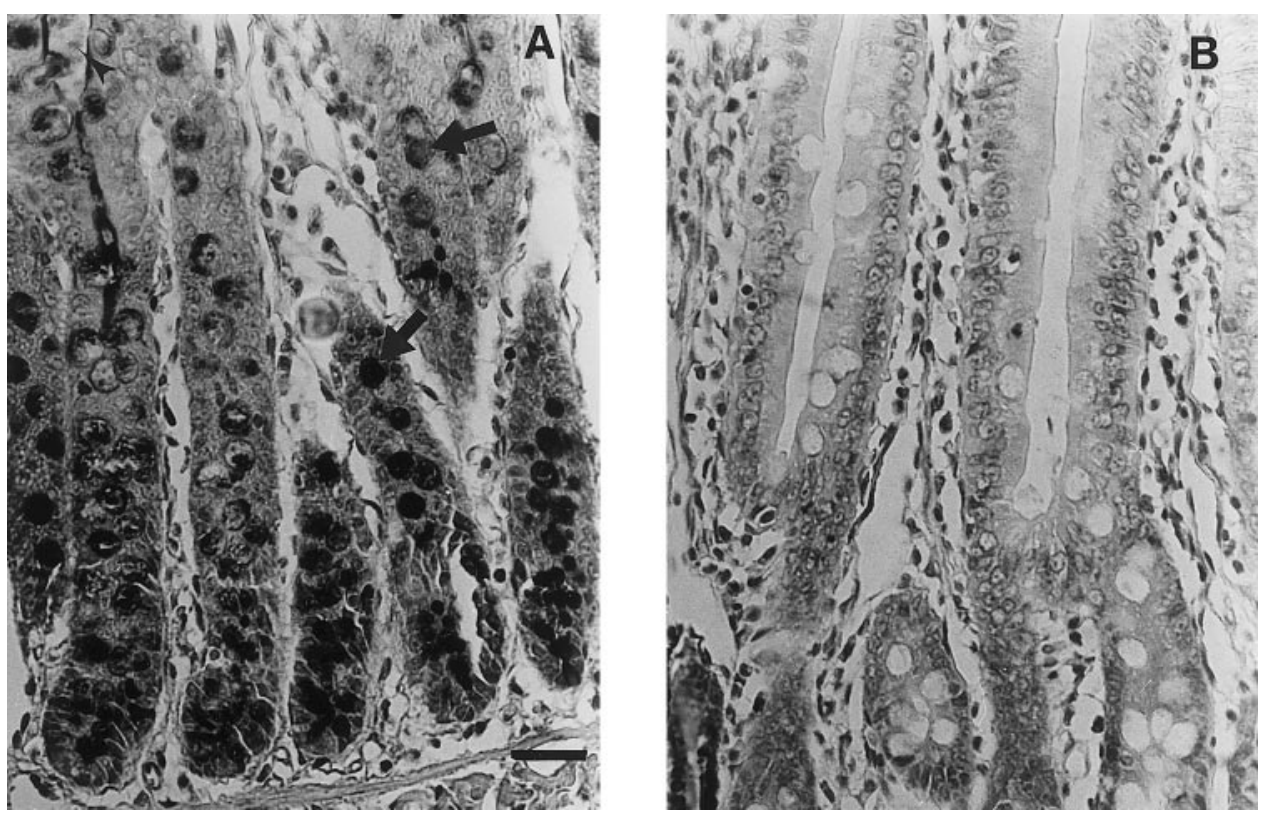

Fig. 1. Section histology of rat intestinal mucosa. Bar $=10 \mu \mathrm{m}$. A: immunohistochemistry of paraffin-embedded rat intestinal tissue after incubation with 1:500 anti-rat intestinal mucin antiserum. This section is oriented with the intestinal lumen at top. Immunolabeling is seen as a brown reaction product. Arrows and arrowhead indicate examples of immunoreactive goblet cells and mucus layer, respectively. $B$ : control immunohistochemistry of an adjacent tissue section. In this experiment, the antiserum (1:500) was first preincubated for $30 \mathrm{~min}$ at $37^{\circ} \mathrm{C}$ with purified rat intestinal mucins $(100 \mu \mathrm{g} / 200 \mu \mathrm{l})$. 
administration of $\mathrm{CH}[5 \%(\mathrm{wt} / \mathrm{vol})]$ induced mucin release (response at $273 \pm 54 \%$ of control loops, $n=6$, $P<0.05$ ). As shown in Fig. 2, the first significant response was observed with $0.1 \%$ (wt/vol) $\mathrm{CH}(277 \pm$ $62 \%$ of controls, $n=6$ ), and the maximal response was obtained with $0.5 \%$ (wt/vol) $\mathrm{CH}(417 \pm 54 \%$ of controls, $n=6)$.

In contrast with $\mathrm{CH}$, luminal administration of native casein [5\% (wt/vol)] did not significantly stimulate mucin secretion in the isolated perfused rat jejunum. Similarly, neither the amino acid mixture [0.5 and $4 \%$ (wt/vol)] nor glutamine (10-100 $\mathrm{mM}$ ) or glutamic acid $(100 \mathrm{mM})$ induced any discharge of mucin.

Enzymatic lactalbumin hydrolysate [LH; 5\% (wt/ vol)] led to a significant increase in luminal mucin content (335 $\pm 56 \%$ of control loops, $n=5)$. On stimulation with $0.5 \%$ (wt/vol) $\mathrm{LH}$, the rise in luminal mucin was less pronounced and did not reach significance (Fig. 3).

The chicken egg albumin hydrolysate [CEAH; 5\% $(\mathrm{wt} / \mathrm{vol})]$ only showed a tendency to increase mucin release, and this increase did not achieve statistical significance (140 $\pm 18 \%$ of control loops, $n=6)$. Administration of $0.5 \%(\mathrm{wt} / \mathrm{vol}) \mathrm{CEAH}$ or of native chicken egg albumin [5\% (wt/vol)] was also without effect on mucin secretion in rat jejunum.

Luminal administration of an enzymatic meat hydrolysate [5\% (wt/vol)] failed to induce any significant increase in the discharge of mucin in rat jejunum $(129 \pm 17 \%$ of control loops, $n=5)$.

\section{Mechanisms Involved in CH-Induced Mucin Secretion}

The effect of the neuronal blocker TTX $\left(10^{-6} \mathrm{M}\right)$ was tested on the mucin secretion induced by intraluminal

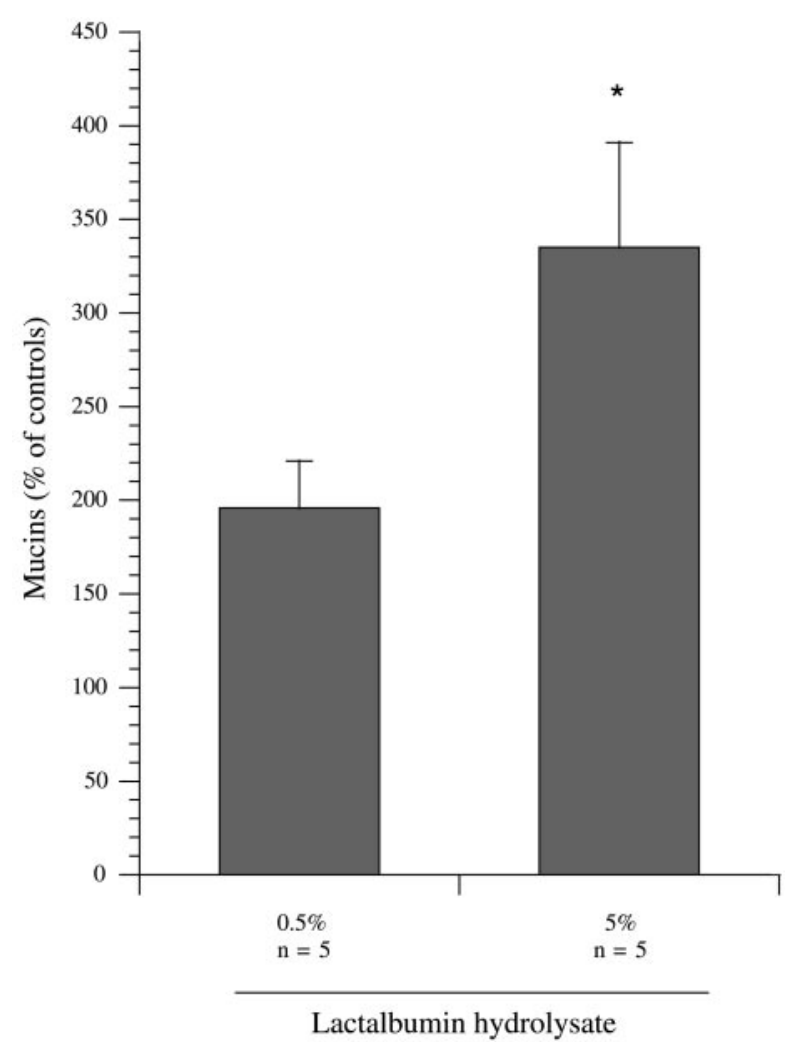

Fig. 3. Effect of luminal lactalbumin hydrolysate on mucin release in rat jejunum. Mucin discharge (\%controls) is given as means \pm SE. $* P<0.05$ vs. controls. A control experiment was produced for every stimulated loop. In related control preparations, the mucin secretion measured at the end of the experiments was $194 \pm 34$ $\mu \mathrm{g} / \mathrm{mg}$ DNA.

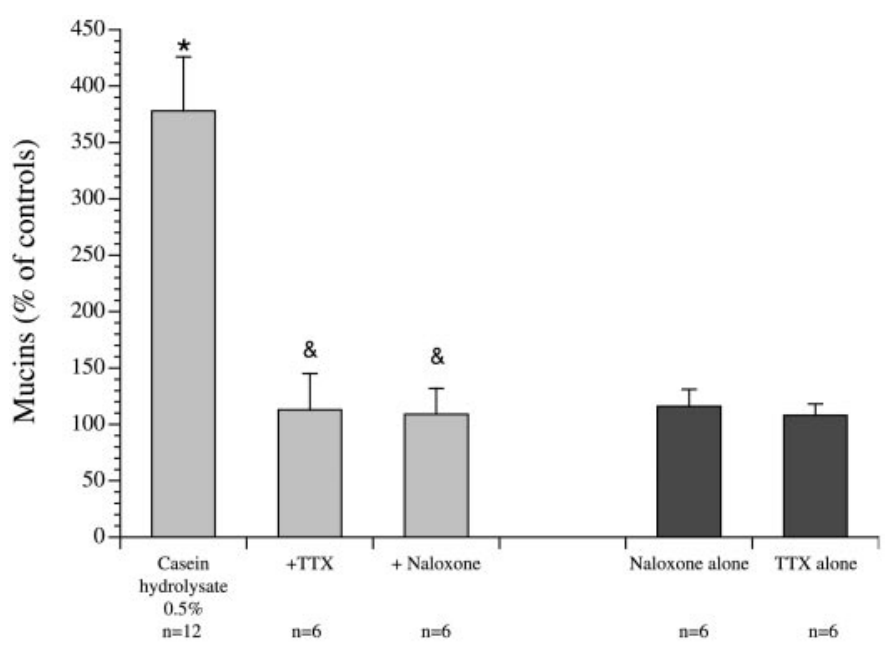

Fig. 4. Effect of luminal casein hydrolysate [CH; 0.5\% (wt/vol)] alone or after blockade with intra-arterial TTX $\left(10^{-6} \mathrm{M}\right)$ or naloxone $\left(10^{-5} \mathrm{M}\right)$ on mucin secretion in rat jejunum. Mucin secretion was $792 \pm 150 \mu \mathrm{g} / \mathrm{mg}$ DNA for $0.5 \%$ (wt/vol) casein hydrolysate $(n=12)$. In blockade experiments, drugs were administered intra-arterially after 2 min of equilibration and over the $30 \mathrm{~min}$ of $\mathrm{CH}$ stimulation. Results are expressed as \%controls, means $\pm \mathrm{SE}$. ${ }^{*} P<0.05$ vs. controls. ${ }^{\&} P<0.05$ vs. $\mathrm{CH}[0.5 \%$ (wt/vol)]. 
administration of $\mathrm{CH}(0.5 \% \mathrm{wt} / \mathrm{vol})$. As shown in Fig. 4, intra-arterial pretreatment with TTX abolished CHinduced jejunal mucin secretion $(P<0.05$ vs. $\mathrm{CH}$ alone). In experiments without $\mathrm{CH}$, TTX $\left(10^{-6} \mathrm{M}\right)$ had no effect on mucin discharge (response at $108 \pm 10 \%$ of controls, $n=6, P>0.05$ ).

Because some casein fragments were shown to behave as opioid receptor ligands, the effect of intraarterial infusion of naloxone (antagonist at $\mu-, \kappa_{-}$, and $\delta$-receptors) on $\mathrm{CH}$-induced mucin secretion was investigated. Interestingly enough, mucin secretion induced by $0.5 \% \mathrm{CH}$ was inhibited by pretreatment with $10^{-5}$ M naloxone. Naloxone alone, in contrast, was without effect on the mucin secretion in isolated rat jejunum (response at $116 \pm 15 \%$ of controls, $n=6 ; P>0.05$ ).

\section{Effect of $\beta-C M-7$ on Mucin Secretion in the Isolated Perfused Rat Jejunum}

Bioactive peptides, including opioid peptides, antihypertensive peptides, antithrombotic peptides, immuno- stimulants, or mineral carriers, are encrypted in the polypeptide chains of caseins and are produced by in vitro or in vivo enzymatic proteolysis. The opioid peptides derived from $\beta$-casein are designated as $\beta$-CMs and include $\beta-\mathrm{CM}-7$ ( $\beta-\mathrm{CM}-7$ ), the $60-66$ fragment of $\beta$-casein.

Luminal administration of $1.2 \times 10^{-4} \mathrm{M} \beta-\mathrm{CM}-7$ produced a sharp rise in the discharge of immunoreactive material ( $563 \pm 65 \%$ of control preparations, $n=6$; $P<0.05)$. This concentration of $\beta-C M-7$ is equivalent to what could be obtained from a $0.5 \%(\mathrm{wt} / \mathrm{vol}) \mathrm{CH}$. The effect of $\beta$-CM-7 was concentration dependent over the range $1.2 \times 10^{-5}-1.2 \times 10^{-4} \mathrm{M}$ (Fig. $5 A$ ), with the first significant response obtained at $6 \times 10^{-5} \mathrm{M}$ (response at $300 \pm 49 \%$ of control loops, $n=6 ; P<0.05$ ).

As can be seen from Fig. $5 B$, pretreatment with $10^{-5}$ $\mathrm{M}$ naloxone inhibited the $\beta$-CM-7-induced mucin release (response at $146 \pm 36 \%$ of controls, $n=7$ vs. $493 \pm 87 \%$ of controls for $\beta$-CM-7 alone, $n=7$; $P<$ $0.05)$.
A

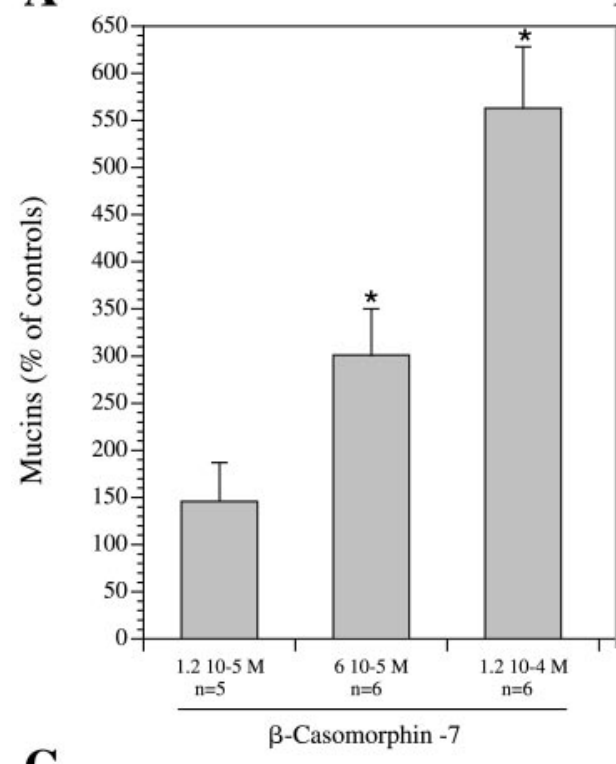

C

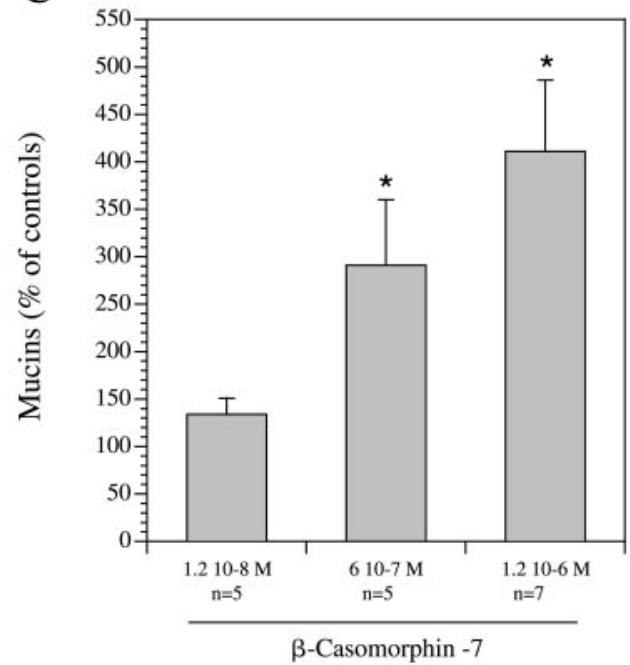

B

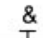

$\&$

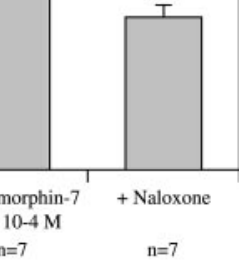

AJP-Gastrointest Liver Physiol • VOL 283 • AUGUST 2002 • www.ajpgi.org 
On intra-arterial infusion, $1.2 \times 10^{-6} \mathrm{M} \beta-\mathrm{CM}-7$ induced jejunal mucin glycoprotein discharge (response at $410 \pm 74 \%$ of control preparations, $n=7 ; P<$ $0.05)$. On infusion of $\beta-C M-7$ at the $6 \times 10^{-7} \mathrm{M}$ concentration, the rise in mucin discharge was also significant (Fig. $5 C$ ).

\section{DISCUSSION}

Studies providing direct evidence for intestinal mucus discharge by nutrients are scarce. Previous investigations showed that dietary fibers and short-chain fatty acids evoke intestinal mucus secretion $(2,35)$. In the present study, we demonstrate, for the first time, that another class of nutrients might regulate the secretory function of rat intestinal goblet cells. Indeed, an enzymatic $\mathrm{CH}$ elicited a strong mucin discharge in the rat jejunal lumen. Beside casein (80\%), milk proteins consist of whey proteins (20\%) (30), chiefly lactalbumin, $\beta$-lactoglobulin, and immunoglobulins. Our data establish that $\mathrm{LH}$ also increased mucin discharge in the lumen of isolated perfused rat jejunum. Interestingly enough, the two other dietary protein hydrolysates we tested (meat and chicken egg albumin hydrolysates) failed to elicit jejunal mucin discharge. Thus all protein hydrolysates are not equally potent in triggering mucin glycoprotein secretion, and mucin discharge in rat jejunum appears to be critically dependent on the source of dietary protein.

$\mathrm{CH}$ produced a dose-dependent release of mucin in the $0.05-0.5 \%$ range, with the first significant response at $0.1 \%$. Because the casein content of bovine milk is $2.7 \%$, the $\mathrm{CH}$-induced intestinal mucin secretion may be physiologically relevant not only in the neonate but also in the adult. In this context, it is worth noting that milk proteins constitute the only source of protein for the neonate and up to $20 \%$ of a human's average food protein intake in the European community and in the United States (30).

Oligopeptides derived from casein seem specific for mediating the effect of this hydrolysate, because native casein and mixed free amino acids were ineffective to induce mucin release in the isolated rat jejunum. Glutamine is one of the most abundant amino acids in casein and is also the prominent metabolic fuel for small intestinal epithelium. In this study, we show that glutamine did not stimulate mucin discharge. Glutamic acid, the other amino acid tested in this study, was also without effect. These results are meaningful because the enzymatic $\mathrm{CH}$ is more likely to mimic dietary protein-derived components found in jejunal chyme than native casein or amino acids.

$\mathrm{CH}$ may stimulate intestinal mucin secretion either directly, namely oligopeptides making contact with the jejunal goblet cells, or indirectly, e.g., via the enteric nervous system. Because several authors previously showed that intestinal mucus cells are under the control of the enteric nervous system $(22,24)$, we addressed the possibility that this pathway could trigger $\mathrm{CH}$-induced mucin secretion. In the present study, the $\mathrm{CH}$-evoked mucin discharge was fully blocked by intra- arterial infusion of TTX, thus suggesting the involvement of intramural neurones. The effect of a synthetic analog of casomorphins, $\beta$-[DAla2,4, Tyr5] CM- $5-\mathrm{NH}_{2}$ on ion transport in rabbit ileum in vitro was also found to be mediated neurally (39). A striking finding was that naloxone, an antagonist at opioid receptors, completely inhibited the mucin release induced by $0.5 \%$ $\mathrm{CH}$. The opioid pathway is thus involved in mediating the secretion of intestinal mucin produced by $\mathrm{CH}$ administration.

The $\mathrm{CH}$ used in our experiments is a highly refined trypsin hydrolysate, and the molecular weights of its oligopeptides are in the 100-1,000 range (informations from the provider). Interestingly, caseins are the source of numerous biologically active peptides such as opioid agonists, antihypertensive peptides, antithrombotic peptides, immunostimulants, and mineral carriers. $\beta$-CMs thus represent the family of exogenous opioid peptides originally isolated from enzymatic digests of bovine milk $\beta$-casein $(37,38)$. They are fragments of the $\beta$-casein sequence $60-70$ (Tyr-Pro-PhePro-Gly-Pro-Ile-Pro-Asn-Ser-Leu) (21), and all contain the $\mathrm{NH}_{2}$-terminal amino acid sequence Tyr-Pro-PhePro. $\beta$-CM-5 (fragment 60-64) and -7 (fragment 60-66) were among the first food-derived opioid peptides described and were found in intestinal chyme or in trypsin hydrolysates (21). In a final analysis, it can be noticed that molecular weights of these $\beta$-CMs $(580$ and 790 for $\beta-\mathrm{CM}-5$ and -7 , respectively) are in adequacy with those observed in our $\mathrm{CH}$.

$\beta$-CMs, first described in the bovine $\beta$-casein sequence, are also found in analogous position in sheep, water buffalo, and human $\beta$-casein $(21,25)$. The wellpreserved primary structure of these peptides suggests that $\beta$-CMs are important biologically active molecules and raises the question of the significance of these opioid peptides in diet. In fact, these $\beta$-CMs are resistant to the action of gastrointestinal proteolytic enzymes (25) and could elicit physiological effects in the intestine. Previous studies showed indeed that $\beta-\mathrm{CMs}$ modulate postprandial release of insulin, glucagon, somatostatin, and pancreatic polypeptide in dogs, stimulate intestinal absorption of electrolytes in rabbit ileum, and significantly prolong intestinal transit time in human and rat $(3,8,31-34)$. $\beta$-CMs have also been proposed for the treatment of diarrhea in calves (31). In the present study, we demonstrate for the first time that $\beta-C M-7$ evokes intestinal mucin secretion in a dose-dependent manner when added to the luminal side of rat jejunum. Together, $\beta$-CMs appear to be important bioactive peptides in the regulation of intestinal function. Luminal concentrations of $\beta$-CMs after ingestion of milk have not been determined, but the highest dose of $\beta$-CM-7 we used in this study $(1.2 \times$ $10^{-4} \mathrm{M}$ ) is equivalent to what could be theoretically obtained from a $0.5 \% \mathrm{CH}$. In the neonate, such an effect of milk protein may be a part of the control of mother on defence mechanisms in the infant's organism, and similar protective effects may be expected in the adult (29). 
The mucin secretion induced by $\beta-\mathrm{CM}-7$ was completely reversed by naloxone, thus confirming the opioid nature of this effect. Opioid receptors can be classified into three types (referred to as $\mu, \kappa$, and $\delta$ ), and $\beta$-CMs may represent agonists for $\mu$-receptors detected in the gut $(30,38)$. Because numerous $\mu$-receptor-immunoreactive nerve fibers have been detected around crypts and blood vessels in the mucosal and submucosal layers of rat intestine (1), a physiological action of $\beta$-CMs requires the passage of active sequences from the lumen to the basolateral side of the epithelium. In keeping with this view, intra-arterial $\beta$-CM-7 administered at a concentration even 100-fold lower than those used for luminal administration evoked a sharp mucin discharge in rat jejunum. The mechanism of $\beta$-CMs absorption is unknown, but studies with $\beta$-lactoglobulin or with insulin $(19,43)$ support the hypothesis of a transcytotic transport of peptides through intestinal enterocytes. The peptides could also be transported intact across Peyer's patches (9).

It was recently shown that the major whey proteins lactalbumin and $\beta$-lactoglobulin also contain bioactive sequences with opioid (lactorphins) or angiotensin Iconverting enzyme inhibitory activity (lactokinins) (23). An attractive hypothesis that could explain mucus secretion induced by LH is the implication of one of these bioactive peptides. Additional experiments with isolated perfused rat jejunum are thus required to determine which of these peptides is implicated in mucus discharge induced by the pancreatic digest of lactalbumin used in our study.

In conclusion, we provide evidence that enzymatic hydrolysates of casein or lactalbumin may modulate mucin secretion in rat jejunum. In contrast, native casein, amino acids, chicken egg albumin and its hydrolysate, or meat hydrolysate does not significantly stimulate mucin discharge. The secretion of mucin induced by $\mathrm{CH}$ or by one of its well-defined components, $\beta-C M-7$, is triggered by opioid receptors and involves a nervous pathway. Our findings extend the list of nutrients or luminal factors liable to stimulate mucus secretion, which may be of interest in preventive nutrition and in gastrointestinal pharmacology.

This work was supported, in part, by the Centre National de la Recherche Scientifique and by the Université Claude Bernard Lyon.

\section{REFERENCES}

1. Bagnol D, Mansour A, Akil H, and Watson SJ. Cellular localization and distribution of the cloned $\mu$ and $\kappa$ opioid receptors in rat gastrointestinal tract. Neuroscience 81: 579-591, 1997.

2. Barcelo A, Claustre J, Moro F, Chayvialle J, Cuber JC, and Plaisancié P. Mucin secretion is modulated by luminal factors in the isolated vascularly perfused rat colon. Gut 46: 218-224, 2000.

3. Ben Mansour A, Tomé D, Rautureau M, Bisalli A, and Desjeux JF. Luminal antisecretory effects of a $\beta$-casomorphin analogue on rabbit ileum treated with cholera toxin. Pediatr Res 24: 751-755, 1988.

4. Cordier-Bussat M, Bernard C, Haouche S, Roche C, Abello J, Chayvialle JA, and Cuber JC. Peptones stimulate cholecystokinin secretion and gene transcription in the intestinal cell line STC-1. Endocrinology 138: 1137-1144, 1997.
5. Cordier-Bussat M, Bernard C, Levenez F, Klages N, LaserRitz B, Philippe J, Chayvialle JA, and Cuber JC. Peptones stimulate both the secretion of the incretin hormone glucagonlike peptide 1 and the transcription of the proglucagon gene. Diabetes 47: 1038-1045, 1998.

6. Cuber JC, Bernard C, Levenez F, and Chayvialle JA. Lipids, proteins and carbohydrates stimulate the secretion of intestinal cholecystokinin in the pig. Reprod Nutr Dev 30: 267-275, 1990.

7. Cuber JC, Vilas F, Charles N, Bernard C, and Chayvialle JA. Bombesin and nutrients stimulate release of CCK through distinct pathways in the rat. Am $J$ Physiol Gastrointest Liver Physiol 256: G989-G996, 1989.

8. Daniel H, Vohwinkel M, and Rehner G. Effect of casein and $\beta$-casomorphins on gastrointestinal motility in rats. J Nutr 120 : 252-257, 1990.

9. Ducroc R, Heyman M, Beaufrere B, Morgat JL, and Desjeux JF. Horseradish peroxidase transport across rabbit jejunum and Peyer's patches in vitro. Am J Physiol Gastrointest Liver Physiol 245: G54-G58, 1983.

10. Forstner G and Forstner J. Gastrointestinal Mucus. Physiology of the Gastrointestinal Tract, edited by Johnson LR. New York: Raven, 1994, p. 1255-1283.

11. Giralt $\mathbf{M}$ and Vergara $\mathbf{P}$. Glucagonlike peptide-1 (GLP-1) participation in ileal brake induced by intraluminal peptones in rat. Dig Dis Sci 44: 322-329, 1999.

12. Guesdon JL, Ternynck T, and Avrameas S. The use of avidin-biotin interaction in immunoenzymatic techniques. $J$ Histochem Cytochem 27: 1131-1139, 1979.

13. Haselbeck A and Hosel W. Description and application of an immunological detection system for analyzing glycoprotein on blots. Glycoconj J 7: 63-74, 1990.

14. Hinegardner TT. An improved fluorimetric assay for DNA. Anal Biochem 39: 197-201, 1971.

15. Hira T, Hara H, and Aoyama Y. Stimulative effect of a casein hydrolysate on exocrine pancreatic secretion that is independent of luminal trypsin inhibitory activity in rats. Biosci Biotechnol Biochem 63: 1192-1196, 1999.

16. Ho SB, Niehans GA, Lyftogt C, Yan PS, Cherwitz DL, Gum ET, Dahiya R, and Kim YS. Heterogeneity of mucin gene expression in normal and neoplastic tissues. Cancer Res 53: 641-651, 1993.

17. Hopman WP, Jansen JB, and Lamers CB. Comparative study of the effects of equal amounts of fat, protein, and starch on plasma cholecystokinin in man. Scand J Gastroenterol 20: 843-847, 1985.

18. Lundin E, Zhang JX, Huang CB, Reuterving CO, Hallmans G, Nygren C, and Stenling R. Oat bran, rye bran, and soybean hull increase goblet cell volume density in the small intestine of the golden hamster. A histochemical and stereologic light-microscopic study. Scand J Gastroenterol 28: 15-22, 1993.

19. Marcon-Genty D, Tome D, Kheroua O, Dumontier AM, Heyman M, and Desjeux JF. Transport of $\beta$-lactoglobulin across rabbit ileum in vitro. Am J Physiol Gastrointest Liver Physiol 256: G943-G948, 1989.

20. Matsuno K, Sasaki N, and Okabe S. Gastric acid secretion in dogs in response to combinations of beer, ethanol and peptone meal-the role of endogenous gastrin. Aliment Pharmacol Ther 14, Suppl 1: 109-115, 2000.

21. Meisel H and Bockelmann W. Bioactive peptides encrypted in milk proteins: proteolytic activation and thropho-functional properties. Antonie Van Leeuwenhoek 76: 207-215, 1999.

22. Phillips TE. Both crypt and villus intestinal goblet cells secrete mucin in response to cholinergic stimulation. Am J Physiol Gastrointest Liver Physiol 262: G327-G331, 1992.

23. Pihlanto-Leppala A. Bioactive peptides derived from bovine whey proteins: opioid and ACE-inhibitory peptides. Trends Food Sci Technol 11: 347-356, 2001.

24. Plaisancié P, Barcelo A, Moro F, Claustre J, Chayvialle JA, and Cuber JC. Effects of neurotransmitters, gut hormones, and inflammatory mediators on mucus discharge in rat colon. Am J Physiol Gastrointest Liver Physiol 275: G1073-G1084, 1998. 
25. Read LC, Lord AP, Brantl V, and Koch G. Absorption of $\beta$-casomorphins from autoperfused lamb and piglet small intestine. Am J Physiol Gastrointest Liver Physiol 259: G443-G452, 1990.

26. Roberts PR, Black KW, Santamauro JT, and Zaloga GP. Dietary peptides improve wound healing following surgery. $\mathrm{Nu}$ trition 14: 266-269, 1998.

27. Sakata T and von Engelhardt W. Influence of short-chain fatty acids and osmolality on mucin release in the rat colon. Cell Tissue Res 219: 371-377, 1981.

28. Satchithanandam S, Vargofcak-Apker M, Calvert RJ, Leeds AR, and Cassidy MM. Alteration of gastrointestinal mucin by fiber feeding in rats. J Nutr 120: 1179-1184, 1990.

29. Schanbacher FL, Talhouk RS, Murray FA, Gherman LI, and Willett LB. Milk-borne bioactive peptides. Int Dairy $J$ 8: 393-403, 1998.

30. Schlimme $\mathbf{E}$ and Meisel H. Bioactive peptides derived from milk proteins. Structural, physiological and analytical aspects. Nahrung 39: 1-20, 1995.

31. Schulte-Frohlinde E, Reindl W, Bierling D, Lersch C, Brantl V, Teschemacher H, and Schusdziarra V. Effects of oral casokefamide on plasma levels, tolerance, and intestinal transit in man. Peptides 21: 439-442, 2000.

32. Schusdziarra V, Holland A, Schick R, de la Fuente A, Klier M, Maier V, Brantl V, and Pfeiffer EF. Modulation of postprandial insulin release by ingested opiate-like substances in dogs. Diabetologia 24: 113-116, 1983.

33. Schusdziarra V, Schick R, de la Fuente A, Holland A, Brantl V, and Pfeiffer EF. Effect of $\beta$-casomorphins on somatostatin release in dogs. Endocrinology 112: 1948-1951, 1983.
34. Schusdziarra V, Schick R, Holland A, de la Fuente A, Specht J, Maier V, Brantl V, and Pfeiffer EF. Effect of opiate-active substances on pancreatic polypeptide levels in dogs. Peptides 4: 205-210, 1983.

35. Shimotoyodome A, Meguro S, Hase T, Tokimitsu I, and Sakata T. Short chain fatty acids but not lactate or succinate stimulate mucus release in the rat colon. Comp Biochem Physiol A Mol Integr Physiol 125: 525-531, 2000.

36. Specian RD and Oliver MG. Functional biology of intestinal goblet cells. Am J Physiol Cell Physiol 260: C183-C193, 1991.

37. Teschemacher $\mathbf{H}$ and Koch G. Opioids in the milk. Endocr Regul 25: 147-150, 1991.

38. Teschemacher H, Koch G, and Brantl V. Milk protein-derived opioid receptor ligands. Biopolymers 43: 99-117, 1997.

39. Tomé D, Ben Mansour A, Hautefeuille M, Dumontier AM, and Desjeux JF. Neuromediated action of $\beta$-casomorphins on ion transport in rabbit ileum. Reprod Nutr Dev 28: 909-918, 1988.

40. Tytgat KM, Bovelander FJ, Opdam FJ, Einerhand AW, Buller HA, and Dekker J. Biosynthesis of rat MUC2 in colon and its analogy with human MUC2. Biochem $J$ 309: 221-229, 1995.

41. Tytgat KM, Buller HA, Einerhand AW, van Deventer SJ, and Dekker J. Role of mucins in inflammatory intestinal diseases. Ned Tijdschr Geneeskd 138: 2386-2390, 1994.

42. Tytgat KM, Buller HA, Opdam FJ, Kim YS, Einerhand AW, and Dekker J. Biosynthesis of human colonic mucin: Muc2 is the prominent secretory mucin. Gastroenterology 107: 13521363, 1994.

43. Ziv E and Bendayan M. Intestinal absorption of peptides through the enterocytes. Microsc Res Tech 49: 346-352, 2000.

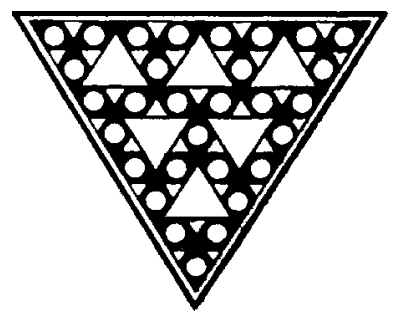

